\title{
New species of Grammolingia Ren, 2002 from the Middle Jurassic of Inner Mongolia, China (Neuroptera: Grammolingiidae)
}

\author{
Chaofan Shi, Yongjie Wang and Dong Ren* \\ College of Life Sciences, Capital Normal University, Beijing, 100048, China. E-mail: rendong@mail.cnu.edu.cn
}

\begin{abstract}
Received 2 July 2012

Accepted 17 December 2012

Published 5 August 2013

Three new species, Grammolingia uniserialis n. sp., Grammolingia binervis n. sp., and Grammolingia sticta n. sp. are described from the Jiulongshan Formation of northeastern China. G. uniserialis n. sp. exhibits a single row of cells in the costal area almost along the entire wing length except the basal part, which is rare in the family and

Key Words firstly found in this genus. G. binervis n. sp. and G. sticta n. sp. add two new patterns of wing markings to the family. A key to the species of Grammolingia Ren, 2002 is

fossil provided. All types of wing markings present in this family are classified.
\end{abstract}

lacewing

Late Mesozoic

wing markings

\section{Introduction}

Neuroptera has a history of more than 270 million years, exhibiting broadest familial diversity in the Mesozoic, especially in the Jurassic and Cretaceous (New 1989; Ponomarenko 2002; Grimaldi \& Engel 2005; Winterton et al. 2010). Grammolingiidae is a small family with limited distribution temporally and geographically, only recorded in the Jurassic of all East Asia and the southern Central Asia, including Daohugou, China; Houtiyn-Hotgor, Mongolia; Shar-Teg, Mongolia; Sai-Sagul, Kyrgyzstan; and Karatau, Kazakhstan. To date, five genera with seventeen species have been reported (Ren 2002; Khramov 2010; Liu et al. 2011; Shi et al. 2011, 2012; Khramov 2012). The genera are distinguished mainly by venational characters, like the separation of the most proximal branch of Rs, the positions of 1A terminating, and the fork positions of $\mathrm{CuA}$ and CuP. Grammolingia, as the type of Grammolingiidae, only consists of its type species Grammolingia boi Ren, 2002, which was found from the Jiulongshan Formation, Middle Jurassic of northeastern China. It can be easily distinguished from other genera by the following characters: the fork of $\mathrm{CuA}$ is proximal to that of CuP, 1A terminated beyond the separation of the first branch of Rs. Although many grammolingiids were recorded from the Mesozoic in China and Mongolia in recent years, no more species were assigned to this genus.

Herein we describe and illustrate three new species of Grammolingia from the Middle Jurassic, Jiulongshan Formation in Daohugou, Inner Mongolia, China, the same locality as the type species of this genus. Besides Grammolingiidae, four other extinct lacewing families (Kalligrammatidae, Panfiloviidae, Saucrosmylidae and Parakseneuridae) and five extant families (Nymphidae, Osmylidae, Psychopsidae, Berothidae, Polystoechotidae) with more than forty species have been recorded from this stratum (Ren 2002; Ren \& Oswald 2002; Ren \& Yin 2002; Ren et al. 2002; Ren \& Yin 2003; Zhang 2003; Ren \& Engel 2007; Makarkin et al. 2009; Wang et al. 2009a, 2009b, 2010a, 2010b; Peng et al. 2010; Yang et al. 2010; Liu et al. 2011; Wang et al. 2011; Yang et al. 2012, 2013). Along with fossil lacewing species from six other formations (Tongchuan Formation, Jinji Formation, Haifanggou Formation, Yixian Formation, Laiyang Formation, Shahai Formation) from the Triassic to the Early Cretaceous (Hong 1980, 1983; Lin 1986; Hong 1988; Yang \& Hong 1990; Ren \& Engel 2008; Yang et al. 2009), they represent diverse groups of Neuroptera from Mesozoic in China.

Institutional abbreviation. CNU, Capital Normal University, Beijing, China.

\footnotetext{
* Corresponding author
} 
Venational abbreviations. 1A, 2A, 3A, Anal veins; C, Costa; costal crossveins, short veins in the costal area going from Subcosta to Costa; costal veinlets, short veins between costal crossveins in longitudinal direction; $\mathrm{CuA}$, anterior cubitus; $\mathrm{CuP}$, posterior cubitus; MA, anterior media; MP, posterior media; R1, the first branch of radius; Rs, radial sector; Sc, Subcosta. Basic terminology of wing venation follows that of New (1989) and Shi et al. (2011).

\section{Materials and methods}

The specimens were examined under a Leica MZ 7.5 dissecting microscope and illustrated with the aid of a drawing tube attachment. Partially magnified images of the specimens were taken under a Nikon SMZ1000. Line drawings were prepared with Adobe Illustrator
CS5 and Adobe Photoshop CS5 graphics software. The photographs were taken by Nikon D100 Digital Camera. Specimens of the new species are deposited in the Key Lab of Insect Evolution and Environmental Changes, the College of Life Sciences, Capital Normal University, Beijing, China (CNU, Ren Dong, Curator).

\section{Systematic paleontology}

Class Insecta Linnaeus, 1758

Order Neuroptera Linnaeus, 1758

Family Grammolingiidae Ren, 2002

\section{Grammolingia Ren, 2002}

Type species. Grammolingia boi Ren, 2002

\section{Key to the species of Grammolingia}

1. Forewing costal area biareolate along entire, or most wing length $\ldots \ldots \ldots \ldots \ldots$

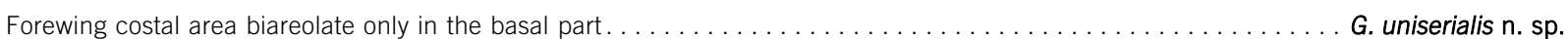

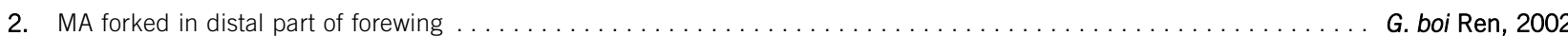

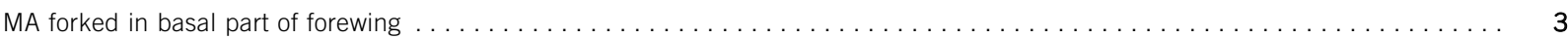

3. Forewing $1 \mathrm{~A}$ dichotomously forked $\ldots \ldots \ldots \ldots \ldots \ldots \ldots \ldots \ldots \ldots \ldots \ldots \ldots \ldots \ldots \ldots$ binervis $\mathrm{n}$ sp.

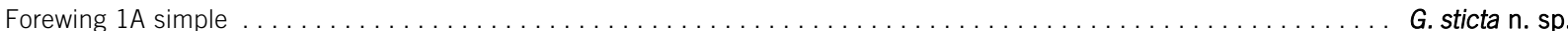

\section{Grammolingia uniserialis n. sp.}

Figures 1A-E, 2, 3

Diagnosis. Forewing costal area dilated at some distance from the base, strongly narrowed basally and smoothly narrowed to middle; costal cells double at basal part, single from the middle to distal part; MA forked at near distal one fifth of forewing length.

Etymology. The specific name derives from Latin "uniserialis", meaning single series, referring to a single row of costal area cells on forewings of the new species.

Holotype. Specimen with almost complete body and four wings spreading out, No. CNU-NEU-NN2010512P/C (Figs 1A-C).

Paratype. Specimen with partial body and a single forewing, No. CNU-NEU-NN2010856 (Figs 1D, E)

Type locality and horizon. Daohugou Village, Wuhua Township, Ningcheng County, Inner Mongolia, China. Middle Jurassic, BathonianCallovian boundary interval, Jiulongshan Formation.

Measurements. Body $18 \mathrm{~mm}$ long (excluding antennae). Forewing 33-39 mm long, 9-14 $\mathrm{mm}$ wide. Hindwing $31 \mathrm{~mm}$ long, $9.5 \mathrm{~mm}$ wide.

Description. Relatively small Grammolingiidae. Compound eyes protruding at both sides of head. Prothorax small, almost the same size of head. Meso- and metathorax dilated, and mesothorax a little bigger than metathorax. Distinct punctures present at mesonotum. Mesoscutellum large, triangular (Fig. 2).

Wings nearly elliptical, somewhat falcate. All wings hyaline, with parallel fuscous stripes across whole wings. Pale speckles sparsely present inside stripes. Tri- chosors present along distal part of costal and outer margins (Figs 2, 3).

Forewing with dense crossveins all over the wing. Costal area broad in the basal one-third of wing length, with two rows of cells. Middle and distal part of costal area much narrower than the basal part, with only one row of cells. Costal crossveins seldom forked, even in the pterostigmal area. Sc, R1 and Rs stem parallel with $\mathrm{C}$ in most part of the wing length, with areas between them almost the same width. Rs arising from R1 near wing base. Rs pectinate branched, with six to nine

Figure 1. Photographs of A, B. Grammolingia uniserialis n. sp. Holotype CNU-NEU-NN2010512P/C; C. CuA in forewing of Grammolingia uniserialis n. sp. Holotype CNU-NEUNN2010512P; D. Grammolingia uniserialis n. sp. Paratype CNUNEU-NN2010856; E. CuA in forewing of Grammolingia uniserialis n. sp. Paratype CNU-NEU-NN2010856; F, G. Grammolingia binervis n. sp. Holotype CNU-NEU-NN2010541P/C; H. CuA in forewing of Grammolingia binervis n. sp. Holotype CNU-NEUNN2010541P; I. 1A in forewing of Grammolingia binervis n. sp. Holotype CNU-NEU-NN2010541P; J, K. Grammolingia sticta $\mathrm{n}$. sp. Holotype CNU-NEU-NN2010732P/C; L. CuA in forewing of Grammolingia sticta n. sp. Holotype CNU-NEU-NN2010732C; M. 1A in forewing of Grammolingia sticta $\mathrm{n}$. sp. Holotype CNUNEU-NN2010732P; N, O. Leptolingia calonervis Shi, Yang et Ren, 2011. Holotype CNU-NEUNN2010500P/C. Scale bars $=2 \mathrm{~mm}$ (for C, E, H, I, L, M), $10 \mathrm{~mm}$ (for A, B, D, F, G, J, K, $\mathrm{N}, \mathrm{O})$. 

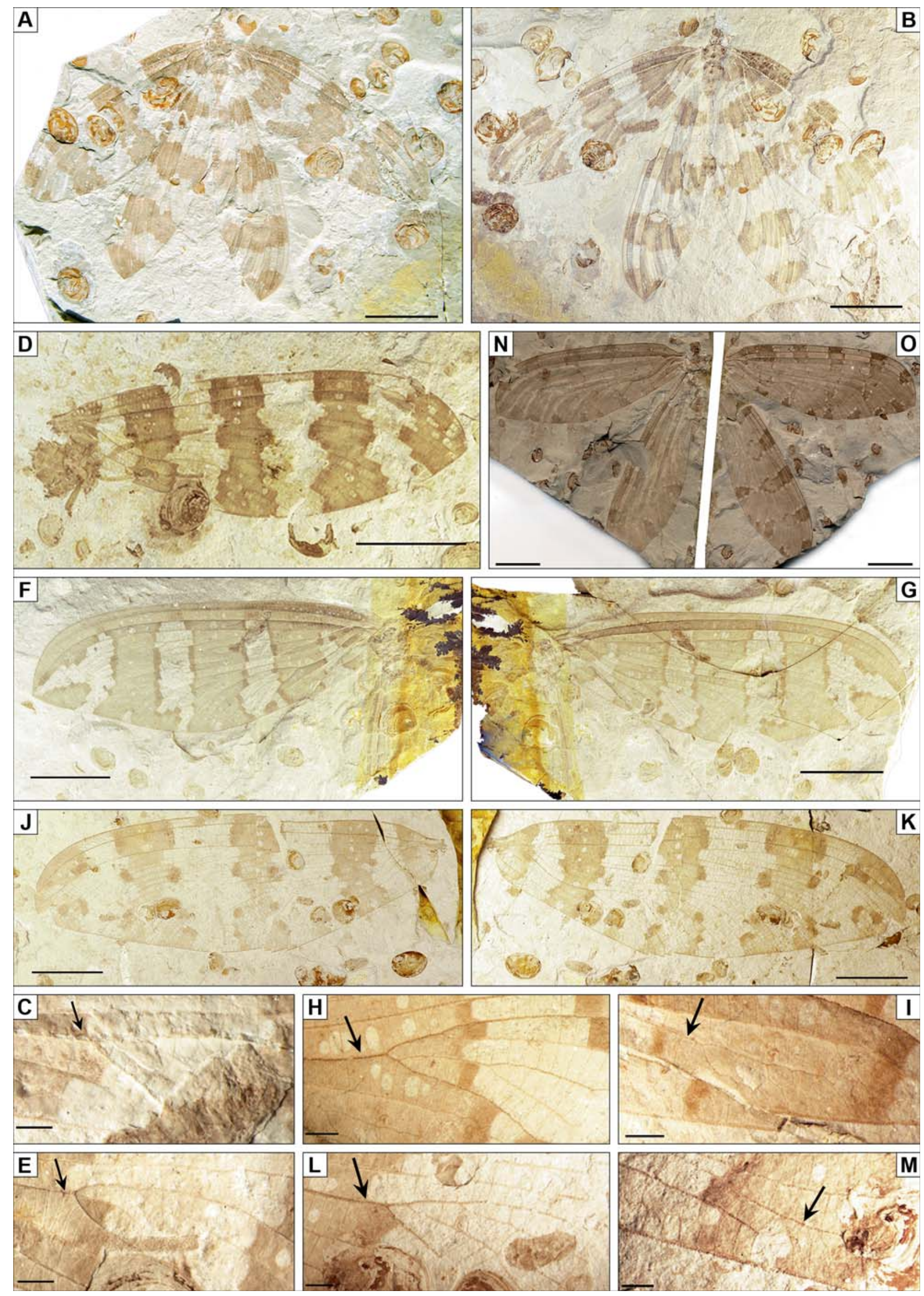


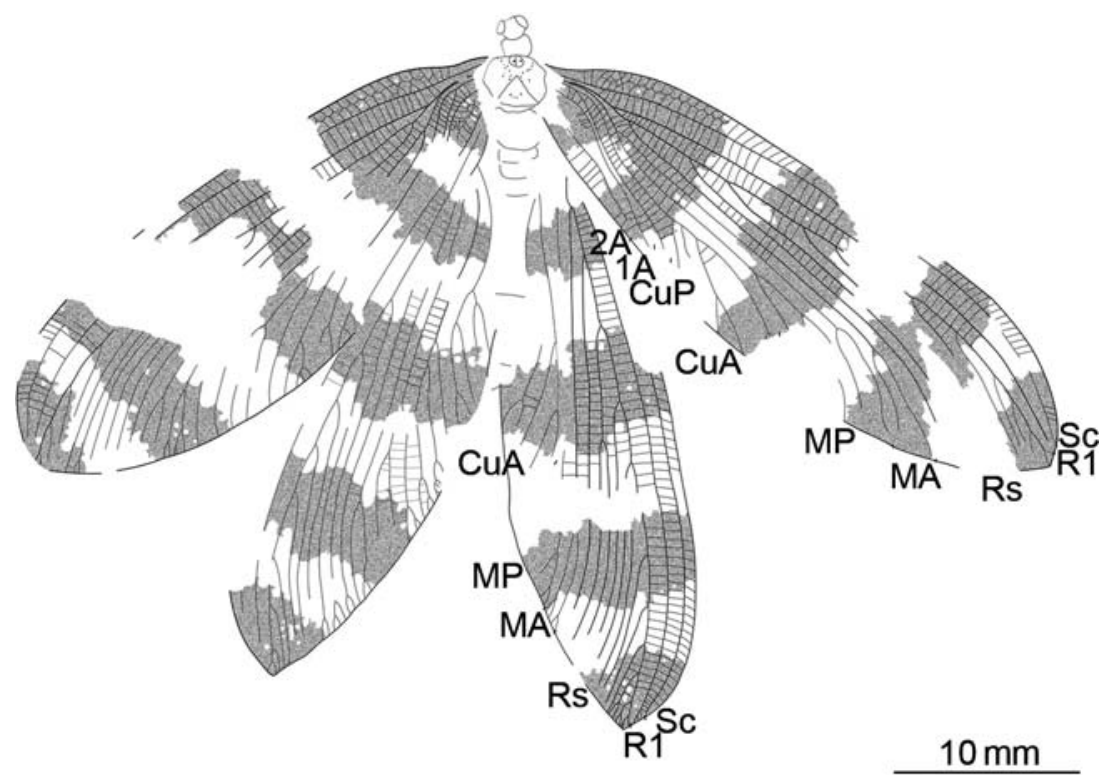

Figure 2. Line drawing of Grammolingia uniserialis $\mathrm{n}$. sp. Holotype CNU-NEUNN2010512P, showing body, venation and wing markings. Scale bar $=10 \mathrm{~mm}$. For abbreviations see main text. branches parallel and curved towards outer margin. All branches of Rs forked distally with several forked deeply occasionally. The first branch of Rs separated from Rs stem proximal to $1 \mathrm{~A}$ terminated. MA coalesced basally with Rs for a very short distance and then separating from it. MA parallel with branches of Rs but dichotomously branched at about distal one fifth of wing length. MP forked close to wing base, the same level as separation of MA from Rs, or slightly distal to it. The anterior branch of MP parallel with MA and forked close to the fork of MA. The posterior branch of MP pectinately branched at the middle of forewing, with two or three main branches. $\mathrm{CuA}$ and $\mathrm{CuP}$ separated at wing base. $\mathrm{CuA}$ forked proximal to the fork of $\mathrm{CuP}$, at basal one-fourth to one-third of wing length, pectinate with rich branches forming an obvious triangular area (Fig 1C) or trichotomously forked (Fig. 1E). 1A convex; a broad area with two or more rows of cells between $1 \mathrm{~A}$ and $2 \mathrm{~A}$ at the basal part. $2 \mathrm{~A}$ simple and shorter. 3A faint (Figs 2, 3).

Hindwing narrower than forewing. Costal area narrow, with one row of cells along entire wing length. Sc, $\mathrm{R} 1$, Rs stem parallel with $\mathrm{C}$, but subcostal area and area between R1 and Rs broader than costal area. Rs pectinate, with more than eight branches parallel and curved towards outer margin. MA and the anterior branch of MP dichotomously forked at distal part of hindwing. Posterior branch of MP pectinate at middle part, with four main branches. CuA curved, forked proximal to the fork of posterior branch of MP, with rich branches. $\mathrm{CuP}$ and anal veins indistinct (Fig. 2).

Remarks. The new species is different from G. boi Ren, 2002 by the single row of cells in the forewing costal area except for the basal part, and distinctly short wing length, i.e. less than $40 \mathrm{~mm}$, compared to $47 \mathrm{~mm}$ of G. boi.

The holotype and paratype represent different configurations of forks of $\mathrm{CuA}$ and Rs branches. But they are associated in one species by the identical characters as: (1) forewing costal area biareolate only in the basal part; (2) MA forked in the distal part; (3) the first branch of Rs separated proximal to $1 \mathrm{~A}$ termination; (4) $\mathrm{CuA}$ forked before $\mathrm{CuP}$.

Moreover, configurations of forks of $\mathrm{CuA}$ and $\mathrm{Rs}$ branches are instable in this family. For example, the different configurations of forks of $\mathrm{CuA}$ in these two specimens indicate different locations where the second branch of $\mathrm{CuA}$ separated. This difference cannot represent change of the main veins, so it is considered as intraspecific variability. Although the fifth branch of Rs in the paratype deeply forked even before the origin of the sixth branch, other than forked distally as other Rs branches in the paratype and all the Rs branches in

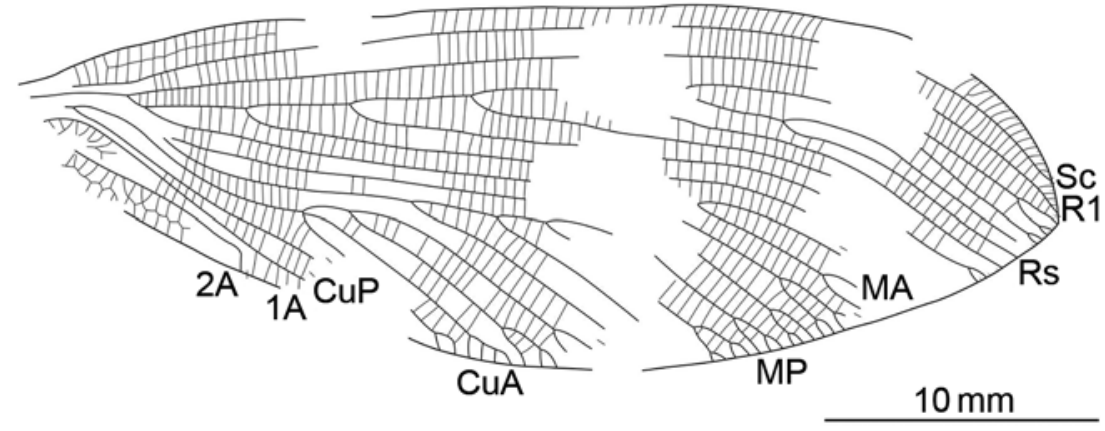

Figure 3. Line drawing of Grammolingia uniserialis $\mathrm{n}$. sp. Paratype CNUNEU-NN2010856, showing venation. Scale bar $=10 \mathrm{~mm}$. For abbreviations see main text. 
the holotype. Such differences of venation in the distal part of wings cannot distinguish species from each other, but represent individuals diversity of G. uniserialis n. sp.

\section{Grammolingia binervis n. sp.}

Figures $1 \mathrm{~F}-\mathrm{I}, 4$

Diagnosis. Forewing costal area with two rows of cells almost entire wing length; MA forked at about basal one fifth of wing length. 1A dichotomously forked. Forewing fuscous, with parallel light stripes across whole wing, borders of stripes obviously darkening, and pale speckles sparsely dispersing outside stripes.

Etymology. The specific name derives from Latin " $b i-$ " (meaning two) and "-nervis" (meaning veins), referring to the two main branches of MA at basal part and dichotomously fork of forewing 1A in the new species.

Holotype. Specimen with a partial body and a single forewing. Body indistinct, only meso- and metathorax visible, No. CNU-NEUNN2010541P/C (Figs 1F-I).

Type locality and horizon. Daohugou Village, Wuhua Township, Ningcheng County, Inner Mongolia, China. Middle Jurassic, BathonianCallovian boundary interval, Jiulongshan Formation.

Measurements. Forewing $45 \mathrm{~mm}$ long, $16.5 \mathrm{~mm}$ wide.

Description. Forewing nearly elliptical and falcate. Forewing fuscous, with four parallel light stripes across whole forewing, borders of stripes obvious and darkening, and pale speckles sparsely dispersing outside stripes (Fig. 4).

Forewing crossveins dense. Costal area almost equally slightly dilated for entire length, more dilated at some distance from wing base, and tapering near apex. Double rows of cells present at costal area almost along whole wing length. Costal crossveins seldom forked. Sc, R1 and Rs stem parallel, forming almost same broad areas between them. Rs arising from R1 close to wing base. Rs pectinate, with seven branches parallel and curved towards outer margin. Most of these branches forked right before terminated, with few deep forked. The third branch of Rs branched closely after separated from Rs stem. The first branch of Rs separated from Rs stem proximal to the position 1A terminated. MA coalesced basally with Rs for a very short distance and then separating from it. MA forked at basal part of forewing, before the separation of the first branch of Rs from Rs stem. Both branches of MA running parallel to branches of Rs, and the posterior branch dichotomously forked at about distal one third of forewing length. MP forked near wing base, but distal to separation of MA and Rs stem. The anterior branch of MP parallel with branches of MA and forked at the same level of the posterior branch of MA. The fork of posterior branch of MP at the middle of wing, with more branches than the anterior one. $\mathrm{CuA}$ and $\mathrm{CuP}$ separated at wing base. $\mathrm{CuA}$ forked before the fork of $\mathrm{CuP}$. $\mathrm{CuA}$ curved and dichotomously forked at basal one fourth of wing length, with rich branches forming a broad triangular area (Fig. $1 \mathrm{H})$. CuP forked near posterior margin, with few branches. 1A long, convex after originated, dichotomously forked (Fig. 1I). Area between $1 \mathrm{~A}$ and $2 \mathrm{~A}$ dilated at the basal part. 2A shorter than 1A. 3A short (Fig. 4).

Remarks. This new species differs from G. boi and G. uniserialis n. sp. by (1) MA forked in the basal part of forewing rather than deeply forked in the distal part of the latter two species; (2) dichotomously forked 1A other than simple of $G$. boi and G. uniserialis n. sp. The new species is also distinguished from G. uniserialis $\mathrm{n}$. sp. by biareolate costal area almost along entire wing length instead of a single row of cells in the costal area except for the basal part of G. uniserialis n. sp.

\section{Grammolingia sticta n. sp.}

Figures $1 \mathrm{~J}-\mathrm{M}, 5$

Diagnosis. Forewing costal area with two rows of cells almost along entire wing length; MA forked at about basal one fifth of wing length. 1A simple. Forewing hyaline, with fuscous stripes across whole forewing, darker spots distributing along borders of stripes and small white speckles sparsely dispersing inside the stripes

Etymology. The specific name derives from Latin "stictus" (spot), referring to distinct dark spots along the borders of wing stripes.

Holotype. Specimen with a single forewing, No. CNU-NEUNN2010732P/C (Figs 1J-M).

Type locality and horizon. Daohugou Village, Wuhua Township, Ningcheng County, Inner Mongolia, China. Middle Jurassic, BathonianCallovian boundary interval, Jiulongshan Formation.

Measurements. Forewing $58.2 \mathrm{~mm}$ long, $20 \mathrm{~mm}$ wide.

Description. Forewing nearly elliptical, hyaline, with five fuscous parallel stripes across whole forewing, darker spots distributing along borders of stripes and small white speckles sparsely dispersing inside the stripes (Fig. 5).

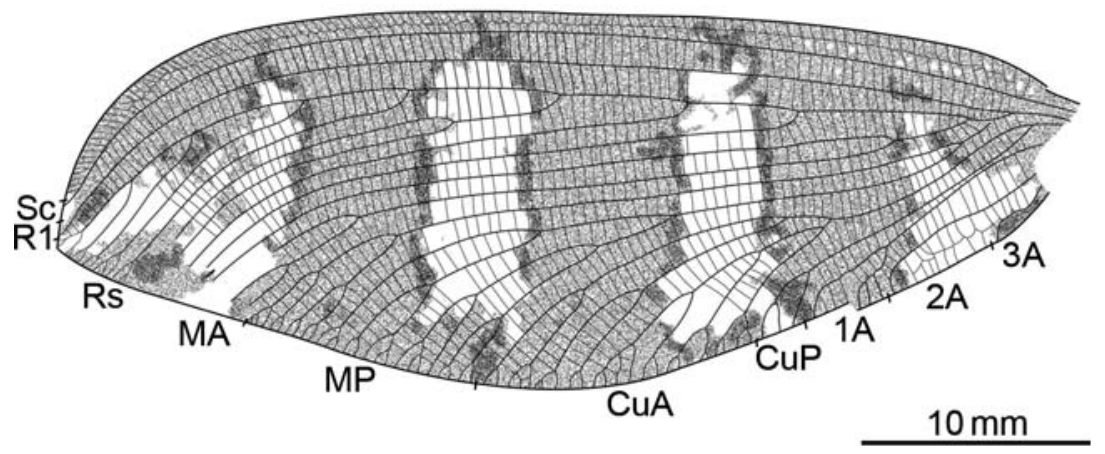

Figure 4. Line drawing of Grammolingia binervis $\mathrm{n}$. $\mathrm{sp}$. Holotype CNU-NEUNN2010541P, showing venation and wing markings. Scale bar $=10 \mathrm{~mm}$. For abbreviations see main text. 


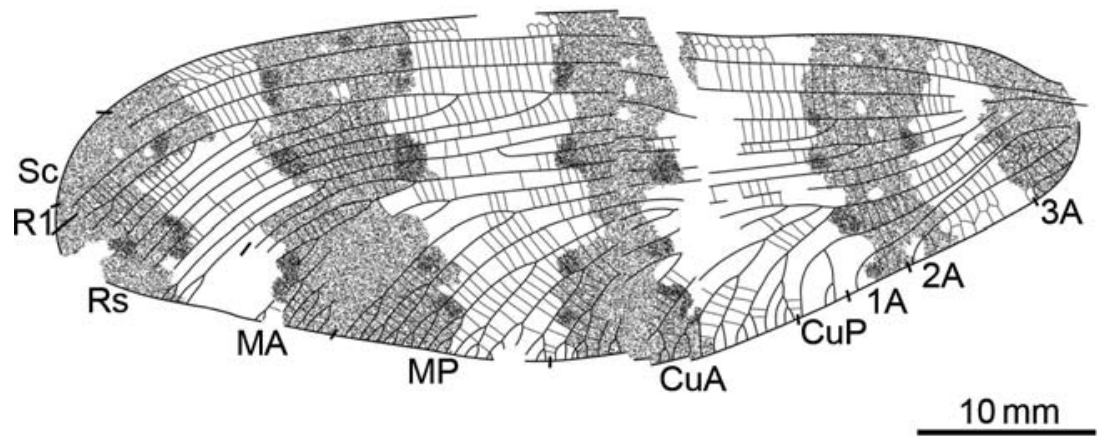

Figure 5. Line drawing of Grammolingia sticta $\mathrm{n}$. sp. Holotype CNU-NEUNN2010732P, showing venation and wing markings. Scale bar $=10 \mathrm{~mm}$. For abbreviations see main text.
Forewing crossveins densely present over the whole wing. Costal area almost equally broad for entire length, slightly broader at some distance from wing base, and tapering around the midway. Costal area biareolate almost along whole wing length. Sc, R1 and Rs stem parallel, forming almost same broad areas between them. Rs arising from R1 near wing base. Rs pectinate, with at least eight branches parallel and curved towards outer margin. Most of these branches forked right before terminated, with few deeply forked. The first branch of Rs separated from Rs stem proximal to the position 1A terminated. The first branch of Rs fused with the second one in the distal part of forewing and bifurcated before termination. MA forked at basal part of forewing, closely before the separation of the first branch of Rs from Rs stem. Both branches of MA running parallel to branches of Rs and dichotomously forked at about distal one third of forewing length. MP forked near wing base, but distal to separation of MA from Rs stem. Both branches of MP dichotomously forked. The anterior one parallel with branches of MA and forked at the same level of them. The fork of the posterior one at the middle of wing, with more branches than the anterior one. $\mathrm{CuA}$ and $\mathrm{CuP}$ separated at wing base. $\mathrm{CuA}$ forked before the fork of $\mathrm{CuP}$. $\mathrm{CuA}$ pectinate, with rich branches forming a broad triangular area (Fig. 1L). CuP forked near posterior margin, with few branches. 1A long and simple (Fig. 1M), convex after originated. Area between $1 \mathrm{~A}$ and $2 \mathrm{~A}$ dilated at the basal part, with two to three rows of cells. 2A shorter than 1A. 3A short (Fig. 5).

Remarks. The new species is different from G. boi and G. uniserialis n. sp. by the basal fork of forewing MA instead of deeply fork in the distal part of the latter two species. The new species is also distinguished from G. uniserialis n. sp. by biareolate costal area almost along entire wing length rather than a single row of cells in the costal area except for the basal part of G. uniserialis n. sp. The new species is mostly similar to G. binervis n. sp., but can be distinguished easily by the simple $1 \mathrm{~A}$ and unique pattern of wing markings.

\section{Discussion}

The family Grammolingiidae is similar to the Late Mesozoic lacewing families Panfiloviidae, Kalligrammati- dae, Aetheogrammatidae and Saucrosmylidae in large wings; closely spaced crossveins in radial area, not arranged in gradate series; MP (indicated as M in Yang et al. 2013) dichotomously forked near wing base; $\mathrm{CuA}$ and $\mathrm{CuP}$ separated at wing base, with $\mathrm{CuA}$ multibranched in the middle part of wings and closely spaced crossveins in the cubital area (Ren \& Oswald 2002; Ren et al. 2002; Ren \& Yin 2003; Ren \& Engel 2008; Makarkin et al. 2009; Wang et al. 2010b, 2011; Yang et al. 2013). But Grammolingiidae is distinguished by the costal area with one series of veinlets between crossveins, resulting in two rows of cells in costal area along whole wing length, or at least at the basal part. In fact, this feature is rare even in the order Neuroptera, only found in some Myrmeleontidae, Ascalaphidae and Chrysopidae (New 1984, 1985; Ponomarenko 1992; Khramov 2012). Besides, Grammolingiidae differs from Aetheogrammatidae on broad basal area between $1 \mathrm{~A}$ and $2 \mathrm{~A}$, with two or three rows of cells; Rs branches separated from Rs stem from wing base, instead of narrow area between $1 \mathrm{~A}$ and $2 \mathrm{~A}$, and Rs branches separated from Rs stem in the distal half part of forewing in Aetheogrammatidae (Ren \& Engel 2008). Grammolingiidae is also distinct from Saucrosmylidae on relatively narrow area between R1 and Rs with single row of cells, but a broad area between R1 and Rs with more than two rows of cells in Saucrosmylidae (Ren \& Yin 2003; Wang et al. 2010b, 2011).

The Late Mesozoic neuropteran groups mentioned above exhibit similar branched $\mathrm{CuA}$ and $\mathrm{CuP}$ in forewings, though most $\mathrm{CuP}$ forked proximal to forks CuA (Panfilov 1980; Ren \& Oswald 2002; Ren \& Yin 2003; Ren \& Engel 2008; Wang et al. 2010b; Shi et al. 2012; Yang et al. 2013). CuA in the forewings of Grammolingia forked proximal to the fork of $\mathrm{CuP}$, which is distinguished from most other grammolingiids. This also can be observed in some kalligrammatids, like Sophogramma lii Yang, Zhao et Ren (Yang et al. 2009).

The new species G. uniserialis n. sp., along with Leptolingia tianyiensis Ren, 2002, Leptolingia imminuta Liu, Shi et Ren, 2011, Chorilingia parvica Shi, Wang, Yang et Ren, 2012, exhibits a single row of cells in the distal part of forewing costal area (Ren 2002; Liu et al. 2011; Shi et al. 2012). They only account for $20 \%$ of the species in the family. Additionally, these species share similar wing length, i.e. about 30- 
$41 \mathrm{~mm}$, much shorter than the others of this family, more or less $50 \mathrm{~mm}$.

Grammolingiidae is distinguished by the conspicuous stripes on wings, which could be classified into four patterns. The most common type is the regular alternately dark and bright stripes across the whole wings parallel, with small white speckles sparsely dispersing inside the fuscous stripes (Figs 1A, B, D). This pattern almost appeared in every genus. The second type is relatively narrower fuscous stripes parallel across the whole light wings, with white speckles arranging along the borders of stripes, stripes sometimes too narrow to separate into two parts. The representative species of this pattern is Leptolingia calonervis Shi, Yang et Ren, 2011 (Figs 1N, O). The third type is light stripes parallel across whole fuscous wings, borders of stripes darken and obvious, and pale speckles sparsely dispersing outside stripes, just like G. binervis n. sp. (Figs 1F, G). The fourth type is fuscous stripes parallel across hyaline wings, with darker spots distributing along borders of stripes and small white speckles sparsely dispersing inside the stripes, such as G. sticta n. sp. (Figs 1J, K). The coloration on wings of grammolingiids could be their strategies to adapt contemporaneous environment, by camouflaging surroundings or destructing the figures of their large wings. Consequently, the diverse patterns of wing markings in this family indicate different environment they lived in.

\section{Acknowledgements}

We sincerely thank Dr. Michael Ohl (Museum für Naturkunde, Leibniz Institute for Research on Evolution and Biodiversity), Dr. Shih Chungkun, Dr. Yang Qiang (College of Life Sciences, Capital Normal University, China) and Prof. Carsten Brauckmann (Institut für Paläontologie, Clausthal University of Technology) for their revision and improvement of our manuscript. We are grateful to the anonymous reviewer for useful advice and comments on previous drafts. This research is supported by National Natural Science Foundation of China Grants 31230065, 31272352, 41272006; the National Basic Research Program of China (973 Program, Grant 2012CB821906); Project of Great Wall Scholar and KEY project of Beijing Municipal Commission of Education (grants KZ201310028033).

\section{References}

Grimaldi, D. \& Engel, M. S. 2005. Evolution of the Insects. Cambridge University Press, New York.

Hong Youchong 1980. Mesozoic Stratigraphy and Palaeontology of Basins of Shaanxi, Gangsu and Ningxia. Geological Publishing House, Beijing.

Hong Youchong 1983. Middle Jurassic Fossil Iinsects in North China. Geological Publishing House, Beijing.

Hong Youchong 1988. Early Cretaceous Orthoptera, Neuroptera, Hymenoptera (Insecta) of Kezuo in western Liaoning Province. Entomotaxonomia 10: 119-130.

Khramov, A. V. 2010. A new lacewing (Insecta: Neuroptera: Grammolingiidae) from the Upper Jurassic of Mongolia. - Paleontological Journal 44 (2): 188-191.
Khramov, A. V. 2012. The new fossil lacewings of Grammolingiidae (Neuroptera) from the Jurassic of Central Asia and Mongolia, with notes on biogeography of the family. - Zootaxa 3478: 297308.

Lin Qibin 1986. Early Mesozoic fossil insects from south China. Paleontologica Sinica 170 (21): 67-68.

Liu Yushuang, Shi Chaofan \& Ren Dong 2011. A new lacewing (Insecta: Neuroptera: Grammolingiidae) from the Middle Jurassic of Inner Mongolia, China. - Zootaxa 2897: 51-56.

Makarkin, V. N., Ren Dong \& Yang Qiang 2009. Two new species of Kalligrammatidae (Neuroptera) from the Jurassic of China, with comments on venational homologies. - Annals of the Entomological Society of America 102 (6): 964-969.

New, T. R. 1984. Revision of the Australian Ascalaphidae (Insecta : Neuroptera). - Australian Journal of Zoology. Supplement series 100: $1-86$.

New, T. R. 1985. A revision of the Australian Myrmeleontidae (Insecta: Neuroptera) III. Distoleontini and Acanthaclisinae. - Australian Journal of Zoology. Supplement series 106: 1-159.

New, T. R. 1989. Lacewings. In Fischer, M. (ed.). Handbook of Zoology. Volume IV Arthropoda: Insecta. Walter de Gruyter, Berlin, New York: p. 132.

Panfilov, D. V. 1980. New representatives of lacewings (Neuroptera) from the Jurassic of Karatau. In Dolin, V. G., Panfilov, D. V., Ponomarenko, A. G. \& Pritykina, L. N. (eds). Fossil insects of the Mesozoic. Naukova Dumka, Kiev, Ukraine: pp. 82-111 [In Russian].

Peng Yuanyuan, Makarkin, V. N., Yang Qiang \& Ren Dong 2010. A new silky lacewing (Neuroptera: Psychopsidae) from the Middle Jurassic of Inner Mongolia, China. - Zootaxa 2663: 59-67.

Ponomarenko, A. G. 1992. New lacewings (Insecta, Neuroptera) from the Mesozoic of Mongolia. In Grunt, T. A. (ed.). New species of fossil invertebrates of Mongolia. - Trudy sovmestnoy sovetskomongolskoy paleontologicheskoy Ekspeditsii 41: 101-110 [In Russian].

Ponomarenko, A. G. 2002. Superorder Myrmeleontidea Latreille, 1802 (= Neuropteroidea Handlirsch, 1903). In Rasnitsyn, A. P. \& Quicke, D. L. J. (eds). History of Insects. Kluwer Academic Publishers, Dordrecht: pp. 176-189.

Ren Dong 2002. A new lacewing family (Neuroptera) from the Middle Jurassic of Inner Mongolia, China. - Entomologica Sinica 9 (12): 53-67.

Ren Dong \& Engel, M. S. 2007. A split-footed lacewing and two epiosmylines from the Jurassic of China (Neuroptera). - Annales Zoologici 57 (2): 211-219.

Ren Dong \& Engel, M. S. 2008. Aetheogrammatidae, a new family of lacewings from the Mesozoic of China (Neuroptera: Myrmeleontiformia). - Journal of the Kansas Entomological Society 81 (3): 161-167.

Ren Dong, Engel, M. S. \& Lu Liwu 2002. New Giant Lacewings from the Middle Jurassic of Inner Mongolia, China (Neuroptera, Polystoechotidae). - Journal of the Kansas Entomological Society 75 (3): 188-193.

Ren Dong \& Oswald, J. D. 2002. A new genus of kalligrammatid lacewings from the Middle Jurassic of China (Neuroptera: Kalligrammatidae). - Stuttgarter Beiträge zur Naturkunde (B) 317: 1-8.

Ren Dong \& Yin Jicai 2002. A new genus and new species of lacewings in the Jurassic of China (Neuroptera: Myrmeleontoidea). Acta Zootaxonomica Sinica 27: 269-273.

Ren Dong \& Yin Jicai 2003. New 'osmylid-like' fossil Neuroptera from the Middle Jurassic of Inner Mongolia, China. - Journal of the New York Entomological Society 111 (1): 1-11.

Shi Chaofan, Wang Yongjie, Yang Qiang \& Ren Dong 2012. Chorilingia (Neuroptera: Grammolingiidae): a new genus of lacewings with four species from the Middle Jurassic of Inner Mongolia, China. - Alcheringa 36 (3): 309-318. 
Shi Chaofan, Yang Qiang \& Ren Dong 2011. Two new fossil lacewing species from the Middle Jurassic of Inner Mongolia, China (Neuroptera: Grammolingiidae). - Acta Geologica Sinica (English Edition) 85 (2): 842-849.

Wang Yongjie, Liu Zhiqi \& Ren Dong 2009a. A new fossil lacewing genus and species from the Middle Jurassic of Inner Mongolia, China. - Acta Palaeontologica Polonica 54 (3): 557-560.

Wang Yongjie, Liu Zhiqi \& Ren Dong 2009b. A new fossil lacewing genus from the Middle Jurassic of Inner Mongolia, China (Neuroptera: Osmylidae). - Zootaxa 2034: 65-68.

Wang Yongjie, Liu Zhiqi, Ren Dong \& Shih Chungkun 2010a. A new genus of Protosmylinae from the Middle Jurassic of China (Neuroptera: Osmylidae). - Zootaxa 2480: 45-53.

Wang Yongjie, Liu Zhiqi, Wang Xin, Shih Chungkun, Zhao Yunyun, Engel, M. S. \& Ren Dong 2010b. Ancient pinnate leaf mimesis among lacewings. - Proceedings of the National Academy of Sciences 107 (37): 16212-16215.

Wang Yongjie, Ren Dong \& Shih Chungkun 2011. An enigmatic Neuroptera family from the Middle Jurassic China with a discussion of the evolutionary significances. In XI. International Symposium on Neuropterology. Ponta Delgada, Portugal, 13-15 June 2011. Book of Abstracts: p. 24.

Winterton, S. L. \& Makarkin, V. N. 2010. Phylogeny of moth lacewings and giant lacewings (Neuroptera: Ithonidae, Polystoechoti- dae) by using DNA sequence data, morphology, and fossils. Annals of the Entomological Society of America 103: 511-522.

Yang Jikun \& Hong Youchong 1990. Drakochrysa, an early Cretaceous new genus of Chrysopidae (Insecta Neuroptera) from Laiyang Basin, Shandong Province. - Geoscience 4 (4): 15-26.

Yang Qiang, Makarkin, V. N. \& Ren Dong 2010. Remarkable New Genus of Gumillinae (Neuroptera: Osmylidae) From the Jurassic of China. - Annals of the Entomological Society of America 103 (6): 855-859.

Yang Qiang, Makarkin, V. N. \& Ren Dong 2013. A new genus of the family Panfiloviidae (Insecta, Neuroptera) from the Middle Jurassic of China. - Palaeontology. In press.

Yang Qiang, Makarkin, V. N., Winterton, S. L., Khramov, A. V. \& Ren Dong 2012. A Remarkable New Family of Jurassic Insects (Neuroptera) with Primitive Wing Venation and Its Phylogenetic Position in Neuropterida. - PLoS ONE 7 (9): e44762. doi:10.1371/journal.pone.0044762.

Yang Qiang, Zhao Yunyun \& Ren Dong 2009. An exceptionally wellpreserved fossil Kalligrammatid from the Jehol Biota. - Chinese Science Bulletin 54 (10): 1732-1737.

Zhang Junfeng 2003. Kalligrammatid lacewings from the Upper Jurassic Daohugou Formation in Inner Mongolia, China. - Acta Geologica Sinica 77: 141-147. 